\title{
Emotional Intelligence: A Critical Success Factor for Selling Funeral Policies
}

\author{
Alphonce Tavona Shiri, PhD Student \\ Department of Management and Entrepreneurship studies \\ University of Kwazulu-Natal, South Africa \\ alphshir@gmail.com \\ Professor Pepukayi Chitakunye \\ University of the Witwatersrand, School of Economic and \\ Management Sciences, South Africa \\ pepukayi.chitakunye@wits.ac.za \\ Dr. Ziska Fields \\ Department of Management and Entrepreneurship studies \\ University of Kwazulu-Natal, South Africa \\ Fields@ukzn.ac.za
}

\section{Doi:10.5901/mjss.2014.v5n20p381}

\section{Abstract}

This study contributes to a deeper understanding of emotional intelligence as a critical success factor in the selling of funeral insurance policies. Insights are drawn from a quantitative study that adopted a convenience sampling approach. The study tested the extent to which emotional competencies are related to job performance of funeral policy sales agents. Thirty Eight (38) agents from an insurance firm in the Midlands province of Zimbabwe participated in this study. A Schutte emotional intelligence test was used to test their overall emotional intelligence as well as their four competencies of emotional intelligence. Agents also responded to questions that tested their ability to handle client rejection and supplied other relevant data, such as age and work experience. The data was analysed using SPSS, and the output revealed that there was a positive relationship between emotional intelligence and performance. The results also revealed that some of the competences on emotional intelligence were insignificantly related to sales agents' performance while others, such as appraisal of emotion and social skills, were significant. The results confirm that emotional intelligence is an important critical success factor in the insurance industry and management should utilise it in planning.

Keywords: Critical success factors, performance, emotional intelligence, emotion segregation, social intelligence

\section{Introduction}

Contemporary and globalised business environments demand that management be abreast with the critical enabling elements that create sustainable business growth and ensure competitive advantage over rivals (Sambamurthy, Baharadwaj and Grover 2003, Ferrier, Smith and Grimm, 1999). In this study, empirical evidence was collected to measure emotional intelligence and to determine whether it is one of the critical elements of success in the funeral policy insurance industry. Mudzimu (2012 p.4) states that "the insurance industry in Zimbabwe is at risk of continuous exposure to high work stress levels because... most Zimbabweans view insurance as a luxury that they cannot afford". The high risk operating environment is partly attributed to the closing down of major industries due to the hyperinflation experienced in 2008 (Pilossof 2009). However, Pilossof (2009) points out that, during 2009, the insurance industry was recovering and that government raised minimum capital requirements to protect policy holders. Given this background, the objective of this study was to understand the critical success factors in the funeral policy insurance industry, with specific reference to the role of emotional intelligence as an element that should be nurtured by management for optimal performance of sales agents. 


\section{Critical Success Factors in Insurance Sales}

Keck, Leigh and Lollar (1995 p.18) posit that critical success factors are necessary "variables which management can influence through its decisions. Such variables can significantly affect the overall competitive positions of the various firms in an industry". In this sense, critical success factors constitute anything that can be controlled by management in order to boost the performance of an organisation (Meibodi and Monavvarian, 2010, Dezdar and Sulaiman, 2009). Within this context, Keck, Leigh and Lollar (1995 p. 19) concluded that critical success factors for sales agents could be "extracted and refined into a set of organisational critical success factors" and they would translate into management activities and decisions about maximising sales agent's performance. Agreeing with this perspective, Sharma and Levy (2003) and Faramillo, Ladik, Marshall and Mulki (2007) maintain that a salesperson's performance is vital to the success and growth of an organisation. This study seeks to establish a deeper understanding of the characteristics that enable the effective performance of a sales agent's function in relation to his emotional intelligence level.

\section{What is Emotional Intelligence?}

Wong and Law (2002 p. 245) state that emotional intelligence can be traced back to the early 1920s when in 1920 Thorndike first proposed the term "social intelligence" and defined it as "the ability to understand and manage men and women, boys and girls...to act wisely in human relations". The theory of emotional intelligence was then developed by Salovey and Mayer (1990) by adopting ideas from Garner's theory of multiple intelligence (Wong and Law, 2002). Rozell, Pettijohn and Parker (2004 p. 405) define emotional intelligence as "the capacity to process emotional information accurately and efficiently, including that information relevant to the recognition, construction and regulation of emotion in oneself and others". Consistent with this perspective, Zhou and George (2003) maintain that emotional intelligence is the competence necessary for maximum utilisation of emotions for decision making. Rozell et al (2004) further explain that emotional intelligence enables individuals to understand their own emotional disposition as well as being able to read the emotions of others, and that this gives them the leverage to be better communicators. Tischler, Biberman and Mckeage (2002) categorise the four dimensions of emotional intelligence as shown in table 1. The four dimensions of emotional intelligence do reveal different aspects and abilities or skills that enable a person to effectively communicate and relate to others.

Table 1: Four dimensions of emotional intelligence

\begin{tabular}{|c|c|c|}
\hline Emotional intel. dimension & Awareness & Skills \\
\hline Emotional awareness & $\begin{array}{l}\text { Self-awareness } \\
\text { Emotional self-awareness } \\
\text { Accurate self-assessment } \\
\text { Self-confidence }\end{array}$ & $\begin{array}{l}\text { Self-management } \\
\text { Self-control } \\
\text { Conscientiousness } \\
\text { Initiative } \\
\text { Achievement } \\
\text { Trustworthiness } \\
\end{array}$ \\
\hline Social emotional awareness & \begin{tabular}{|l|} 
Social awareness \\
Empathy \\
Service orientation \\
Organisational-awareness
\end{tabular} & \begin{tabular}{|l} 
Social skills \\
Leadership \\
Influence \\
Developing others \\
\end{tabular} \\
\hline Emotional management & \begin{tabular}{|l} 
Self-awareness \\
Emotional self-awareness \\
Self-supportive
\end{tabular} & $\begin{array}{l}\text { Independence } \\
\text { Adaptability } \\
\text { Less impulsiveness }\end{array}$ \\
\hline Relationship management & $\begin{array}{l}\text { Positive social attitudes } \\
\text { Empathy }\end{array}$ & $\begin{array}{l}\text { Good relations } \\
\text { Social extroversion }\end{array}$ \\
\hline
\end{tabular}

Source: Tischler et al. ( 2002 p. 205)

Table 1 is reflective of the emotional intelligence concept advanced by Lam and Kirby (2010 p. 134) when they state that it is "...not a single trait or ability but rather a composite of distinct emotional reasoning abilities; perceiving, understanding, and regulating emotions". This implies that, through emotional intelligence, one can utilise the ability to understand one's own and others' emotions for successful and effective communication as well as relationship development. Furthermore, a person who is highly emotionally intelligent can interpret the facial and physical expressions 
of others and adjust their own expressions and maintain a mutual and beneficial interaction with others (Zeidner, Matthews and Roberts, 2004).

\section{Emotional Intelligence and Sales Agents' Performance}

Kidwell, Hardesty, Murtha and Sheng (2011) argue that emotions represent an important phenomenon that has a bearing on sales professionals' performance. This view is also shared by Deeter-Schmelz and Sojka (2003) who state that emotional intelligence can be a vital competence that separates high performing sales agents from the average sales agent. Similarly, Deeter-Schmelz and Sojka (2003 p. 217) in their exploratory study, questioned the relationship between performance and emotional intelligence, and found what they called a "possible link". The phrase "possible link" raises questions about the strength of the relationship. Therefore, this study collects data that can be statistically analysed and can confirm a position as to whether there is a symbiotic relationship between emotional intelligence and performance.

Further, the current study seeks to determine the extent to which emotional intelligence is a critical success factor in the insurance industry, particularly focusing on the selling of funeral policies. Sonjka and Deeter-Schmelz (2002) argue that empathy is an important element that is necessary for sales agents to understand customers' needs and develop relationships with them. Furthermore, Sonjka and Deeter-Schmelz (2002) posit that intrapersonal dimensions, such as emotional awareness, are more important relationship management as they help the salesperson to portray a realistic image in the mind of the potential customer. Therefore, it is important to understand the dimensions of emotional intelligence that are most important for sales agents.

Rozell et al. (2004 p.405) used a self-report emotional intelligence measure to question the relationship between emotional intelligence and customer orientation in sales professionals. Although the latter concluded that there was a positive relationship between emotional intelligence and performance, the researchers did not statistically compute components of emotional intelligence against variables of performance, such as sales performance records. They deduced that, since those who exhibited high customer orientation also showed high levels of emotional intelligence, then there was a positive association between emotional intelligence and performance. Cote' and Miners (2006 p.2) administered a Mayer, Salovey, Caruso Emotional Intelligence Test (MSCEIT) and found that emotional intelligence had an inverse relationship with cognitive intelligence in predicting job performance.

While the latter's findings provide useful information on emotional intelligence, they do not address the relationship of each dimension to salesperson's job performance. The generalizability of the research findings can also be questioned as the performance ratings of the employees in question were supervisor evaluations of subordinate performance, which could be subjective or contain errors. Therefore, there is a need to analyse results of actual employee performance data and not observations of the performance which could be subjective depending on the type of relationship existing between the supervisor and the subordinate.

Sy, Trams and O'Hara (2006) examined the relationship between emotional intelligence and job performance for restaurant franchise employees. Although Sy et al (2006) found that emotional intelligence correlates positively with job performance, they did not measure actual individual output against emotional intelligence level of the individual. Law and Wong (2004) suggested that there is a need to associate the employee's personal output with their assessed emotional intelligence level.

Although they found a weak correlation between emotional intelligence and job performance, Law and Wong (2004 p.494) recommend "the use of non-self report measures of El" where the respondents would be free to select the answer that best describes their emotional intelligence so that the researcher can then compute their emotional intelligence level, using the provided scores. This view is also shared by (Goldenberg, Matheson and Mantler, 2006; Bruckett, Rivers, Shiffman, Lerber and Salovey 2006).

Austin (2004) found that intrapersonal dimensions of emotional intelligence were not related to insurance sales agents' performance, but interpersonal dimensions of emotional intelligence were significantly related to sales agents' performance. These findings therefore establish the need to confirm the real position of the relationship of emotional intelligence components to performance. There is a need to confirm which emotional intelligence components or dimensions are strongly linked to performance and which are linked weakly to performance.

\subsection{Direction of cause effect relationship between El and performance}

Slaski and Cartwright (2002 p.67) confirm that, although they found "...a significant link between emotional intelligence....and performance", their research failed to establish "the direction of the causality". This means that Slaski and Cartwright (2002) could not establish whether emotional intelligence dimensions were positively or negatively related 
to performance. There were no conclusive findings relating to the cause/effect relationship between emotional intelligence and performance. One could not tell whether emotional intelligence and performance are inversely related. This means that the research carried out so far is only providing limited evidence of a relationship, without going deeper to uncover the quality or strength of the relationship and the extent to which one can control performance through raising or lowering the level of emotional intelligence. Deeter-Schmelz and Sojka (2003) concur with the lack of causality argument when they suggest that it is important to conduct research to find out which components of emotional intelligence are more critical for sales agents. This means that a ranking of the competencies in relation to performance is required. Rozell et al (2004) also maintain that future research should focus on interrogating the level of relationship between emotional intelligence and other variables for performance in sales agents. These writers posit that another variable that scaffolds the performance of sales agents is the social desirability of the agent. This therefore means that literature has not yet filled the gap on the association of emotional intelligence and other performance variables of sales agents, and is an opportunity for this research to analyse such data.

\subsection{Emotional intelligence and emotional segregation for performance}

Lam and Kirby (2002 p. 140) maintain that individuals do not cause emotions to occur but "...once emotions occur and are recognised by the cognitive systems of the brain, the ability to guard against distracting emotions and to build on enhancing emotions facilitates individual task performance as well as team performance" In the insurance sales industry, agents experience a lot of sales rejections. What this means is that, when interacting with potential clients, an agent with high emotional intelligence should be in a position to control the negative feedback from the client, and amplify those emotions that will help him to redirect a rebuttal using certain catch phrases for a successful outcome. Lam and Kirby (2002 p.140) call this technique 'buffering', in which the agent would compress and isolate negative emotions such that they do not obstruct the task at hand. However, Lam and Kirby (2002) acknowledge that their research did not involve social tasks and that they could not give a conclusive position on the relationship between emotional intelligence and buffering of negative emotions for performance.

\section{Research Methodology}

The study adopted a quantitative approach, as well as a convenience sampling approach. There were thirty eight participants for this study. These were funeral insurance sales agents for a funeral insurance company located in the Midlands province of Zimbabwe. The company, whose name has been withheld, has branches in each of the three major cities of the Midlands province.

This insurance company was selected for the study because it is fairly new to the market and the agency has to compete with the well-established companies that have been operating for over thirty years. The choice of company was influenced by the need to reduce the influence of other variables, such as brand name, and draw a fair conclusion as to the role of emotional intelligence. The participants answered a set of questions on a test and supplied information about their age and work experience. The emotional intelligence test used in this study is consistent with that used by Schutte, Malouff, Hall, Haggerty, cooper, Golden and Dornheim (1998).

The respondents were asked to respond on a Likert scale from zero to five, to questions like "I am aware of the non-verbal messages other people send" . The test assessed sales agents' traits or self perceptions that are relevant for success in selling funeral insurance policies. The facets of emotional intelligence tested using the Schutte et al (1998) emotional intelligence tests included optimism, appraisal of emotions, social skills, and utilization of emotions. The test is a self-report questionnaire constituting 33 items or questions that measure the four subscales of optimism, appraisal of emotions, social skills, and utilization of emotions on a 1 to 5 Likert scale. This type of test was recommended by Law \& Wong (2004) who were satisfied with their research findings and the reliability of the method applied, but recommended the development of a test that would involve participants choosing the best answer to describe their emotional intelligence rather than a test in which the participants directly state or evaluate their own abilities; for instance, in situations where the respondents gauge whether their social emotional awareness is at 30 percent. The funeral sales agents were also asked to rate how well they handle rejections and buffer negative emotions. Permission was granted by management to access data on the performance of the participants. Six months data on the funeral policy sales agents was then released by the administrator. 


\section{Results}

The results from the emotional intelligence test were computed in IBM SPSS Version 21 and reflected in tables:

\subsection{Emotional intelligence relationship to performance output}

The relationship between emotional intelligence and sales agents' performance was determined using IBM SPSS version 21 as shown below in table 2. Table 2 shows the correlations output for sales agents performance in relation to emotional intelligent dimensions such as emotional management.

Table 2: The correlation between emotional intelligence and performance

\begin{tabular}{|c|c|c|c|c|c|c|c|}
\hline \multicolumn{8}{|c|}{ Person's correlations } \\
\hline & & 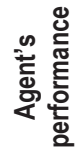 & 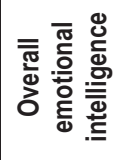 & 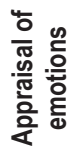 & 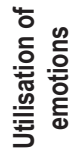 & 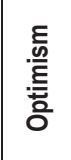 & $\frac{\omega}{\frac{\omega}{0}}$ \\
\hline Agent's performance & Pearson correlations Sig.(2-tailed) N & $\begin{array}{c}1 \\
38\end{array}$ & $\begin{array}{c}.303 \\
.466 \\
38 \\
\end{array}$ & $\begin{array}{c}.279 \\
.504 \\
38 \\
\end{array}$ & $\begin{array}{c}.012 \\
.977 \\
38 \\
\end{array}$ & $\begin{array}{c}.030 \\
.944 \\
38 \\
\end{array}$ & \begin{tabular}{|c|}
.452 \\
.261 \\
38 \\
\end{tabular} \\
\hline Overall emotional intelligence & Pearson correlations Sig.(2-tailed) N & $\begin{array}{c}.303 \\
.466 \\
38 \\
\end{array}$ & $\begin{array}{c}1 \\
38\end{array}$ & $\begin{array}{c}.509 \\
.198 \\
38 \\
\end{array}$ & $\begin{array}{c}.932^{\star \star} \\
.001 \\
38 \\
\end{array}$ & $\begin{array}{c}.425 \\
.294 \\
38 \\
\end{array}$ & \begin{tabular}{|c}
$.880^{\star \star}$ \\
.004 \\
38 \\
\end{tabular} \\
\hline Appraisal of emotions & Pearson correlations Sig.(2-tailed) N & $\begin{array}{c}.279 \\
.504 \\
38 \\
\end{array}$ & $\begin{array}{c}.509 \\
.198 \\
38 \\
\end{array}$ & $\begin{array}{c}1 \\
38\end{array}$ & $\begin{array}{c}.406 \\
.318 \\
38 \\
\end{array}$ & \begin{tabular}{|c|}
-.498 \\
.209 \\
38 \\
\end{tabular} & \begin{tabular}{|c|}
.259 \\
.536 \\
38 \\
\end{tabular} \\
\hline Utilisation of emotions & Pearson correlations Sig.(2-tailed) N & $\begin{array}{c}.012 \\
.977 \\
38\end{array}$ & $\begin{array}{c}.932^{\star \star} \\
.001 \\
38\end{array}$ & $\begin{array}{c}.406 \\
.318 \\
38\end{array}$ & $\begin{array}{c}1 \\
38\end{array}$ & \begin{tabular}{|c|}
.427 \\
.292 \\
38 \\
\end{tabular} & \begin{tabular}{|c|}
$.728^{\star}$ \\
.041 \\
38 \\
\end{tabular} \\
\hline Optimism & Pearson correlations Sig.(2-tailed) N & $\begin{array}{c}.030 \\
.944 \\
38 \\
\end{array}$ & $\begin{array}{c}.425 \\
.294 \\
38 \\
\end{array}$ & $\begin{array}{c}-.498 \\
.209 \\
38 \\
\end{array}$ & $\begin{array}{c}.427 \\
.292 \\
38 \\
\end{array}$ & $\begin{array}{c}1 \\
38\end{array}$ & $\begin{array}{c}.493 \\
.214 \\
38 \\
\end{array}$ \\
\hline Social skills & Pearson correlations Sig.(2-tailed) N & $\begin{array}{c}.452 \\
.261 \\
38 \\
\end{array}$ & $\begin{array}{c}.880^{\star *} \\
.004 \\
38 \\
\end{array}$ & $\begin{array}{c}.259 \\
.536 \\
38 \\
\end{array}$ & $\begin{array}{c}.728^{*} \\
.041 \\
38\end{array}$ & $\begin{array}{c}.493 \\
.214 \\
38 \\
\end{array}$ & $\begin{array}{c}1 \\
38\end{array}$ \\
\hline
\end{tabular}

${ }^{\star *}$ Correlation is significant at the 0.01 level (2-tailed)

${ }^{*}$ Correlation is significant at the 0.05 level (2-tailed)

Source: Own compilation using output from IMB SPSS version 21

The results as indicated in table 3 show that there was a positive correlation of 0.303 between emotional intelligence and sales agents performance. Table 3 below shows that emotional intelligence dimensions or independent variables explain sales agents' performance or the dependent variable by 79.6 percent or $r$ square of 0.796 .

Table 3: Model summary for emotional intelligence and performance

\begin{tabular}{|c|c|c|c|}
\hline Model & $\mathbf{R}$ & R square & Adjusted r square \\
\hline 1 & $.892^{\mathrm{a}}$ & .796 & .286 \\
\hline
\end{tabular}

Source: Own compilation using output from IBM SPSS version 21

The computations as displayed in table 3 reveal that overall emotional intelligence competencies were related to performance with an adjusted $R^{2}=0.286$. There is evidence that the emotional intelligence of funeral sales agents in this study was related to their job performance as the adjusted $r$ square was positive. 
The relationship between an agent's performance and his or her age and work experience was tested as revealed in table 4 below.

Table 4: Correlations on age and work experience in relation to performance

\begin{tabular}{|c|c|c|c|c|}
\hline & & 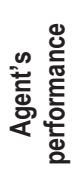 & 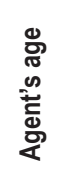 & 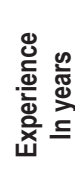 \\
\hline Agent's performance & Pearson's correlations Sig. (2-tailed) N & $\begin{array}{c}1 \\
38\end{array}$ & $\begin{array}{l}.428 \\
.290 \\
38\end{array}$ & $\begin{array}{c}.168 \\
.690 \\
38\end{array}$ \\
\hline Agent's age & Pearson's correlations Sig. (2-tailed) N & $\begin{array}{l}.428 \\
.290 \\
38\end{array}$ & $\begin{array}{c}1 \\
38\end{array}$ & $\begin{array}{l}.360 \\
.381 \\
38\end{array}$ \\
\hline Experience in years & Pearson's correlations Sig. (2-tailed) N & $\begin{array}{c}.168 \\
.690 \\
38\end{array}$ & $\begin{array}{c}.360 \\
.381 \\
38\end{array}$ & $\begin{array}{c}1 \\
38\end{array}$ \\
\hline
\end{tabular}

Source: Own compilation using output from IBM SPSS version 21

From table 4 above, it is noteworthy that age has a stronger relationship to a funeral sales person's performance than is the relationship with work experience.

Table 5 below shows the results of IBM SPSS version 21 output which reveals the relationship between age and years of experience variables to performance. Work experience and age are the two variables being analysed against performance and table 6 below shows that the relationship is very weak.

Table 5: Model summary for work experience and age in relation to performance

\begin{tabular}{|c|c|c|c|}
\hline Model & $\mathbf{R}$ & R square & Adjusted r square \\
\hline 1 & $.428^{\mathrm{a}}$ & -.183 & -.144 \\
\hline
\end{tabular}

a Predictors: (constant) experience in years, agent's age

Source: Own compilation using output from IMB SPSS version 21

The results in table 6 show an $r^{2}=.183$, and an adjusted $r^{2}$ of -.144 . This shows a weak relationship and, after adjusting the $r^{2}$ for errors, reveals a negative relationship.

This study also tested the funeral policy sales agents for their ability to handle client rejection. The results summarised in table 6 below show the relationship between agents' ability to handle rejection and their level of emotional intelligence.

Table 6: Model summary for work experience and age in relation to performance

\begin{tabular}{|c|c|c|c|}
\hline Model & R & R square & Adjusted r square \\
\hline 1 & $.824^{\mathrm{a}}$ & .680 & .626 \\
\hline
\end{tabular}

a Predictors: (constant) handle rejection

Source: Own compilation using output from IMB SPSS version 21

The relationship between agents' ability to handle rejection and their level of emotional intelligence was found to be strong with an adjusted $r$ square of 0.626 


\section{Discussion}

The objective of this study was to find out the role of emotional intelligence as a critical success factor for funeral sales agents for a small firm in the Midlands province of Zimbabwe. The results of the study show that there was a positive correlation between emotional intelligence and performance. The results indicated an $r^{2}$ of .30, and adjusted $r^{2}$ of .28 . This finding adds to the literature on the relevance of emotional intelligence in the workplace and, in particular, the funeral sales insurance industry. While overall emotional intelligence did not exhibit a strong positive relationship to performance, breaking it down to its components revealed interesting properties about emotional intelligence.

This view is confirmed by Mayer et al in Lassk and Shepherd (2013:26) who theorise that emotional intelligence is "an eclectic mix of traits, many dispositions, such as happiness, self-esteem, optimism, and self management". Drawing from the findings, we argue that it is important to analyse the relationship of emotional intelligence to sales performance by its individual components rather than in total.

The findings reveal that some of the components may be more applicable in one type of industry than in others. Using the four components of emotional intelligence, as suggested in the literature (Zeidener et al. 2004) it emerged that appraisal of emotions had a positive correlation of 0.27 to job performance. This means that as sales agents talk to a potential client, they should have the competency to assess or read into the emotional reactions of the client and adjust the insurance product or plan initially being offered to a plan that the potential client would show emotional signs that they are more comfortable to. Social skills had the highest correlation to job performance of 0.45 . This means that social skills are an important trait that sales agents should posses. It equips them with the ability to network and communicate well with current and potential clients. Utilisation of emotions and optimism exhibited a very weak relationship of 0.012 and 0.030 respectively.

The findings therefore reveal that for funeral sales agents, the two most useful components for performance are appraisal of emotions and social skills. Social skills is an emotional competency skill which arms the sales agent with a positive social attitude, which is required to achieve high performance (Rozell, Pettijohn and Parker 2006, Cote' and Miners, 2006) and, as the results show, it had the highest correlation to performance. The literature suggests that appraisal of emotions helps the agents to accurately assess themselves and boost their self-confidence (Goldenberg et al. 2006) which is also required to close on sales negotiations.

Corr and Gray (1995 p. 242) state that "salespeople encounter frequent criticism and rejection and this... leads to lowered self-esteem and feelings of dejection, with a consequent drop in motivation". This means that rejection by clients has a bearing on the performance of sales agents. Lam and Kirby (2002) argue to the contrary, that a person with high emotional intelligence is able to buffer negative emotions and utilise their emotions to overcome negative feedback from the client.

This study computed empirical data from funeral sales agents' performance records against their self-evaluated ability to overcome rejection, and found a positive correlation $r^{2}$ of 0.63 . There was a correlation of 0.89 between ability to handle rejection and emotional intelligence levels of sales agents.

This study found a weak relationship between funeral sales agents' job performance and work experience, with an $r^{2}$ of 0.16 . There was a higher correlation between the age of the agents and performance of $r^{2}$ equal to 0.42 . These findings confirm the position advanced by Johlke (2006) who states that the relationship between sales performance and experience is normally insignificant.

\subsection{Validation and reliability}

The findings from this study were validated through computation of the Cronbach alpha coefficient. The overall alpha for emotional intelligence and its dimensions was 0.78 , which is a good indicator of strong internal consistency among the emotional intelligence dimensions of the funeral sales agents and reveals that an agent with a high level of overall emotional intelligence also exhibited the high levels of emotional intelligence dimensions required for success in the sale of funeral policies. The Cronbach alpha for an agent's ability to handle rejections was 0.90 , an agent's age was 0.60 , and an agent's work experience was 0.29 .

The Schutte et al (1998) emotional intelligence test was confirmed for internal consistency with a Cronbach's alpha of .87 for 31 participants. The Schutte et al (1998) emotional intelligence scale was tested for predictive validity through a longitudinal study and the results showed that the test significantly predicted first year college students' success. In other studies, the global emotional intelligence score and three of the four branches have shown acceptable levels of reliability, but reliability of the utilization of emotion subscale was moderate in some studies (Gardner and Qualter, in press, Saklofske, Austin and Minksi, 2003). Empirical research supports the existence of the four subscales of optimism or 
mood regulation, appraisal of emotions, social skills and utilization of emotion (Saklofske et al 2003). The Schutte et al (1998) used in this study therefore is a validated research instrument, which the developers have provided free access for academic research and students' research.

\subsection{Managerial implications}

This study contributes to the understanding of emotional intelligence as a critical success factor in selling funeral policies. The results show that a positive relationship between emotional intelligence and sales performance exists. When the dimensions of emotional intelligence are analysed separately, it showed that appraisal of emotions and social skills were important traits of emotional intelligence to be used in the selling of funeral policies. Therefore, it is important that management in the insurance industry incorporate activities that enhance the emotional intelligence of individuals as they plan workshops and training sessions for sales agents. This study has revealed that emotional intelligence is an important component for the successful execution of sales agents' duties. Incorporating emotional intelligence testing in the interviewing process of insurance sales agents may help insurance companies to curtail huge costs of hiring and training.

\subsection{Limitations and recommendations}

This research was carried out on one funeral insurance company. A study of this nature, which involves calculating the association between and among variables, should be carried out on a different companies in order to reduce the element of bias. However, the research findings in this study do contribute to knowledge and understanding of the emotional intelligence theory. The findings confirmed positions already established in other literature, such as the insignificance of the relationship between experience and sales performance. This research was focused on funeral insurance sales agents so the findings may not translate to other areas within the insurance industry as selling other products, such as those found in financial markets, may require the exhibiting of different sets of emotions and, consequently, different emotional competencies. It would also be more beneficial to carry out a study that encompasses clients' perspectives in order to gain a complete understanding of the success factors relative to different types of insurance products and the role of emotional intelligence in that dynamic.

\section{Conclusion}

This study was carried out to uncover the relationship between emotional intelligence and performance in the funeral insurance policy industry. It revealed that there is a positive relationship between emotional intelligence and insurance sales performance. Emotional intelligence can be better understood when its components are investigated separately in their association with the phenomenon in question. It was learned that, depending on the industry and the job, some emotional intelligence competencies may be insignificant as predictors of performance. In this study, it can be concluded that appraisal of emotions and social skills are significantly related to performance of funeral sales agents.

\section{References}

Austin, E.J. (2004). An investigation of the relationship between trait emotional intelligence and emotional task performance. Personal and Individual Differences, 36(1), 1855-1864.

Bruckett, M.A., Rivers, S.E., Shiffman, S., Lerber, N. \& Salovey, P. (2006). Relating emotional abilities to social functioning: A comparison of self-report and performance measures of emotional intelligence. Journal of Personality and Social Psychology, 91(3), 780-795.

Corr, P.J., \& Gray, J.A. (1995). Attributional style, socialization and cognitive ability as predictors of sales success: A predictive validity study. Journal of Personality and Individual Differences, 18(2), 241-252.

Cote, S., \& Miners, C.T.H. (2006). Emotional intelligence, cognitive intelligence and job performance. Science Quarterly, $51(1), 1-28$.

Dawyers, S., Hill, J., \& Martin, W. (2000). An empirical investigation of critical success factors in the selling process for homogenous goods. Journal of Personal Selling and Sales Management, 20(3, 151-159.

Deeter-schmelz, D.R., \& Sonjka, J.Z. (2003). Developing effective salespeople: Exploring the link between emotional intelligence and sales performance. The international Journal of Organisational Analysis, 11(3), 211-220.

Dezdar, S., \& Sulaiman, A. (2009). Successful enterprise resource planning implementation: Taxonomy of critical factors. Industrial Management and Data Systems, 109(8), 1037-1052.

Faramillo, F., Ladik, D.M., Marshall, G.W., \& Mulki, J.P. (2007). A meta-analysis of the relationship between sales orientation-customer orientation (SOCO) and salesperson job performance.

Journal of Business and Industrial Marketing, 22(5), 302-310. 
Ferrier, W.J., Smith, K.G., \& Grimm, C.M. (1999). The role of competitive action in market share erosion and industry dethronement. A study of industry leaders and challengers. Academy of Management Journal, 42(4), 372-388.

Gardner, K.J., \& Qualter, P. (in press). Concurrent and incremental validity of three trait emotional intelligence measures. Special issue on Emotional Intelligence. Australian Journal of Psychology.

Goldenberg, I., Matheson, K., \& Mantler, J., (2006). The assessment of emotional intelligence: A comparison of performance based and self-report methodologies. Journal of Personality Assessment, 86(1), 33-45.

Johlke, MC., (2006). Sales presentation skills and salesperson job performance. Journal of Business and Industrial Marketing, 21(5), 311-319.

Keck, K.L., Leigh, T.W., \& Lollar, J.G., (1995). Critical success factors in captive, multi-line insurance agency sales. Journal of Personal Selling and Sales Management, 15(1), 17-33.

Kidwell, B., Harddesty, D.M., \& Urtha, B.R. (2011). Emotional intelligence in marketing exchanges. Journal of Marketing, 75(1),78-95.

Lam, L.T., \& Kirby, S.L. (2002). Is emotional intelligence an advantage? An exploration of the impact of emotional and general intelligence on individual performance. Journal of Social Psychology, 142(1), 133-143.

Lassk, F.G., \& Shepherd, C.D. (2013). Exploring the relationship between emotional intelligence and salesperson creativity. Journal of Personal Selling \& Sales Management, 33(1), 25-37.

Law, K.S., \& Wong, C. (2004). The construct and criterion validity of emotional intelligence and its potential utility for management studies. Journal of Applied Psychology, 89(3), 483-496.

Meibodi, L.A., \& Monavvarian, A. (2010). Recognising critical success factors (CSF) to achieve the strategic goals of SAIPA Press. Business Strategy Series, 11(2), 124-133.

Mudzimu, P.T.V. (2012). Work stress, work-home interference, and organisational culture of insurance employees in Zimbabwe. MComthesis, Pretoria. University of South Africa.

Pilossof, P. (2009). Dollarization in Zimbabwe and the death of an industry. Review of African Political Economy, 36(12), $294-299$.

Rozell, E.J., Pettijohn, C.E., \& Parker, R.S., (2004). Customer-oriented selling: exploring the roles of emotional intelligence and organisational commitment. Psychology and Marketing, 21(6),405-424.

Rozell, E.J., Pettijohn, C.E., \& Parker, R.S. (2006). Emotional intelligence and dispositional affectivity as predictors of performance in salespeople. Journal of Marketing Theory and

Practice, 14(2), 113-124

Saklofske, D.H., Austin, E.J., \& Minski, P.S. (2003). Factor structure and validity of a trait emotional intelligence measure. Personality and Individual Differences, 34, 707-721

Salovey, P. \& Mayor, J.D. (1990). Emotional intelligence. Imagination, Cognition and Personality 9(1), 185-211.

Sambamurthy, V., Bharadwa, J.A., \& Grover, V. (2003). Shaping agility through digital options: Reconceptualising the role of information technology in contemporary firms. MIS Quarterly, 27(2), 237-263.

Schutte, N.S., Malouff, J.M., Hall, L.E., Haggerty, D.J., Cooper, J.T., Golden, C.J., Dornheim, L.(1998). Development and validation of a measure of emotional intelligence. Personality and Individual Differences, 25, 167-177

Sharma, A., \& Levy, M. (2003). Salespeople's affect toward customers: Why should it be important for retailers? Journal of Business Research, 56(7), 523-528.

Sonjka, J.Z., \& Deerter-schmelz, D.R. (2002). Enhancing the emotional intelligence of salespeople. Mid-American Journal of Business, 17(1), 43-50.

Sy, T., Tram, S. \& O'hara, L.A. (2006). Relation of employee and manager emotional intelligence to job satisfaction and performance. Journal of Vocational Behaviour 68(1), 465-476.

Tischler, L., Biberman, J., \& Mckeage, R. (2002) Linking emotional intelligence, spirituality and workplace performance: definitions, models and ideas for research. Journal of Managerial Psychology, 17(3), 203-218.

Wong, C., \& Law, K.S. (2002). The effect of leader and follower emotional intelligence on performance and attitude: An exploratory study. Leadership Quarterly, 13(1), 243-274.

Zeidner, M., Matthews, G., \& Roberts, R.D. (2004). Emotional intelligence in the workplace: A critical review. Applied psychology: An International Review, 53(3), 371-399.

Zhou, J., \& George, J.M. (2003). Awakening employee creativity: The role of leader emotional intelligence. Leadership Quarterly, 14(1), 545-568. 